\title{
A Newly Recorded Sea Star (Asteroidea: Forcipulatida: Asteriidae) from the East Sea, Korea
}

\author{
Taekjun Lee, Sook Shin* \\ Department of Life Science, Sahmyook University, Seoul 139-742, Korea
}

\begin{abstract}
Sea stars were collected with fishing nets between depths of 40-150 m from the Gangwon-do coastal region, East Sea. Specimens were identified as Evasterias echinosoma Fisher, 1926 belonging to the family Asteriidae, which is new to the Korean fauna. This species was characterized by strong external spines and a general size of more than $200 \mathrm{~mm}$, thus the largest sea star identified in Korea to date. Its morphological characteristics are described here with photos. Thirty two asteroid species including E. echinosoma have been reported from the East Sea of Korea.
\end{abstract}

Keywords: taxonomy, sea star, Asteroidea, Asteriidae, Evasterias, East Sea

\section{INTRODUCTION}

Asteriidae is the largest family of order Forcipulatida and comprises 221 species within 43 genera worldwide (Mah, 2009). In Korea, Asteriidae was composed of 8 species and 7 genera: Aphelasterias japonica, Asterias amurensis, Coscinasterias acutispina, Distolasterias nipon, Evasterias retifera, Lethasterias fusca, L. nanimensis chelifera, and Sclerasteruas satsumana (Shin, 2010). Among them genus Evasterias includes four species worldwide; E. derjungini, E. echinosoma, E. retifera, and E. troscheli (Mah, 2009), while E. retifera has been reported from the East Sea, Korea (Shin, 1995). In this study, twelve specimens were collected using fishing nets between depths of 40-150 m from five coastal districts in Gangwon-do from Aug 2009 to Dec 2010. They were subsequently identified as E. echinosoma, which is newly recorded in Korea. The specimens were preserved in 95\% methyl alcohol, and their important morphological characters were photographed using stereo- and light-microscopes (Nikon SMZ1000, Nikon Eclipse 80i; Nikon Co., Tokyo, Japan). Thus to date, thirty two asteroid species, including this species, have now been recorded from the East Sea, Korea (Rho and Shin, 1980; Shin, 1995; Shin and Rho, 1996; Lee and Shin, 2009, 2010).

\section{SYSTEMATIC ACCOUNTS}

Class Asteroidea de Blainville, 1830

Order Forcipulatida Perrier, 1884

Family Asteriidae Gray, 1840

Genus Evasterias Verrill, 1914

Key to the Korean species of genus Evasterias

1. Dorsal spines crowded, inferomarginal plates on margin of $\mathrm{arm}$ E. retifera

- Dorsal spines well spaced, inferomarginal plates and upper side of ventrolateral plates on margin of arm

E. echinosoma

${ }^{1 *}$ Evasterias echinosoma Fisher, 1926 (Fig. 1A-N)

Evasterias echinosoma Fisher, 1926: 2; 1930: 152; Hayashi, 1943: 229; D’yakonov, 1968: 115; Mah, 2009: 254498.

Materials examined. 1 specimen, Sacheon, 11 Aug 2009, Shin S, at $40 \mathrm{~m}$ depth; 1 specimen, Geojin, 27 Dec 2009, Lee T, at $80 \mathrm{~m}$ depth; 1 specimen, Chodo, 27 Dec 2009, Shin $\mathrm{S}$, at $40 \mathrm{~m}$ depth; 3 specimens, 22 Jun 2010, Lee T, at $70 \mathrm{~m}$ depth; 2 specimens, Geojin, 15 Sep 2010, at $80 \mathrm{~m}$ depth; 1 specimen, Imwon, 17 Sep 2010, Lee T, at $40 \mathrm{~m}$ depth; 1 specimen, Daejin, 17 Oct 2010, Shin S, at $80 \mathrm{~m}$ depth; 1 specimen, Geojin, 17 Oct 2010, Lee T, at $110 \mathrm{~m}$ depth; 1 specimen, Jangho, 26 Dec 2010, Shin S, at $150 \mathrm{~m}$ depth.
(C) This is an Open Access article distributed under the terms of the Creative Commons Attribution Non-Commercial License (http://creativecommons.org/ licenses/by-nc/3.0/) which permits unrestricted non-commercial use, distribution, and reproduction in any medium, provided the original work is properly cited.
*To whom correspondence should be addressed

Tel: 82-2-3399-1717, Fax: 82-2-3399-1729

E-mail: shins@syu.ac.kr 

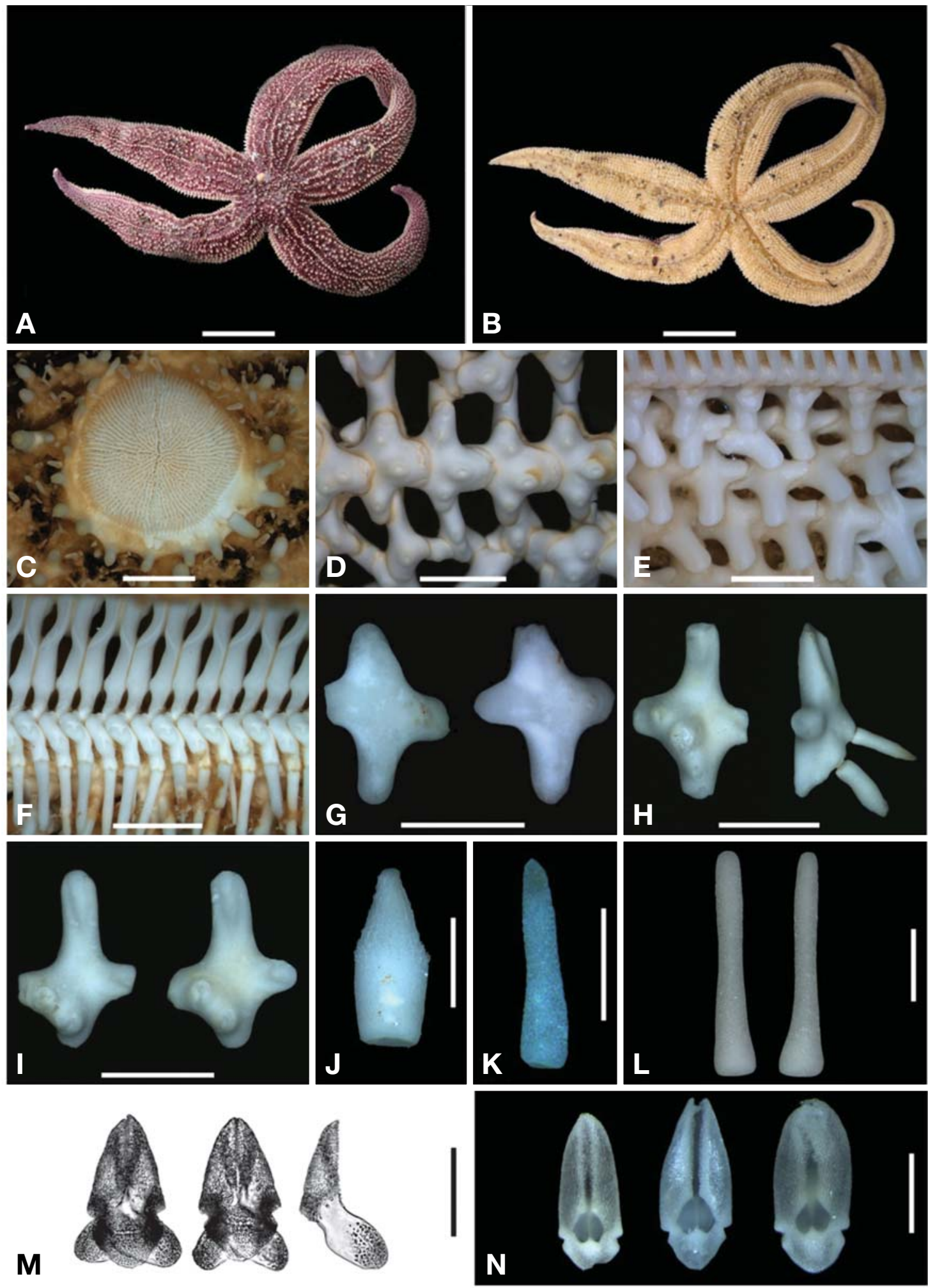

Fig. 1. Evasterias echinosoma. A, Dorsal side; B, Ventral side; C, Madreporite; D, Carinal plates; E, Series of ventrolateral plates and a part of ambulacral plates; $F$, Ambulacral plates, and adambulacral plates with spines; $G$, Superomarginal plates; $H$, Inferomarginal plates with spines; I, Ventrolateral plates; J, Large dorsal spine; K, Slender dorsal spine; L, Adambulacral spines; M, Crossed pedicellariae; N, Small lanceolate, large lanceolate, and unguiculate straight pedicellariae. Scale bars: A, B=5 cm, C-I=3 mm, J-L=1 $\mathrm{mm}, \mathrm{M}=200 \mu \mathrm{m}, \mathrm{N}=0.5 \mathrm{~mm}$. 
Description. $R=214-252 \mathrm{~mm}, \mathrm{r}=34-41 \mathrm{~mm}, \mathrm{R}=6.2-6.3 \mathrm{r}$. Five arms long and very strong, somewhat depressed in basal part, one-fifth of arm the widest, tapering to tip, depressed towards amburacral groove, dorsal surface convexed and ventral surface almost flattened. Dorsal skeleton irregularly mesh form, composed with three or four lobed large primary plate and small atypical second plates. Carinal plate four lobed, arranged in a longitudinal series, usually with three spines in a plate consisting of two slender spines and one larger strong spine. Two types of dorsal spines located: larger strong spine apart from each other, uniformly sized, subconical shaped, usually one in a plate and slender spine finger shaped, usually two in a plate. Madreporite large, distinctly circular, flattened, situated nearby margin of disk. Marginal plates longitudinal four lobed, regularly arranged in two longitudinal series, similar size and adjacent to ventrolateral plates. As superomarginal plate located in dorsolateral side, inferomarginal plate defined margin of arm. Superomarginal plate usually with one spine, but often two at proximal part of arm, each spine a little longer, stronger and more tapered than dorsolateral spine, and encircled by crossed pedicellariae. Inferomarginal spines usually two in a plate, but rarely three, slender ones located in upper side. Ventrolateral plate four lobed, usually arranged in six regular longitudinal series, gradually decreasing in size toward furrow, usually two spines in a plate, but innermost plate have one spine with a tuft of small crossed pediciellariae and a large straight pedicellaria. Adamburacral plate short, broad, round triangle form, with three spines: furthermost spine more slender and shorter than inner spines with blunt tips. Two kinds of straight pedicellariae present: larger one usually unguiculate type with strongly interdigitated apex, usually in dorsal side, rarely in marginal plates and nearby oral spines; large lanceolate one with shallow interdigitated apex and small serrated valve. Smaller one lanceolate type with small serrated valve, usually in dorsal side, adambulacral plates, and oral spines, and rather few in border of amburacral and adamburacral plates. Small crossed pedicellariae very numerous, located singly or in a group in dorsal side, and marginal, ventrolateral and oral parts. Color in life burgundy in dorsal side, almost white in dorsal spines, orange in madreporite, and dark yellow in ventral side.

Distribution. Korea (East Sea), Avatka Bay, KamchatkaOkhotsk Sea, southern Bering Sea (Bristol Bay-Unalaska).

Remarks. This species is characterized by its large burgundy body covered with numerous strongly short white spines. This was first recorded by Fisher (1926), and then Hayashi (1943), and D'yakonov (1968) collected many specimens in northern Hokkaido, Okhotsk Sea, and Bering Sea, respectively. Six series of ventrolateral plates have been observed in our specimens, but Fisher (1930) usually described five or six series, rarely four, and D'yakonov (1968) usually described five or six series, rarely seven. A number of ventrolateral series seems to be different according to the body size. This species was reported as the largest sea star in marine fauna of Russia (D'yakonov, 1968), and also in Korea.

\section{ACKNOWLEDGEMENTS}

This work was supported by Sahmyook University Research Fund in 2011 and partially by the project on publication of Flora and Fauna of Korea of the National Institute of Biological Resources (NIBR) under the Ministry of Environment, Korea.

\section{REFERENCES}

D'yakonov AM, 1968. Sea stars (asteroids) of the USSR seas. [Translation from keys to the fauna of the USSR. No, 34. Zoological Institute of the Academy of Sciences of the USSR, 1950]. Israel Program for Scientific Translations, Jerusalem, pp. 1-152.

Fisher WK, 1926. A new sea star of the genus Evasterias. Proceeding of the United States National Museum, 69:1-5.

Fisher WK, 1930. Asteroidea of the North Pacific and adjacent waters. Part. III. Forcipulata (Consulted). Bulletin of the United States National Museum, 76:1-356.

Hayashi R, 1943. Contributions to the classification of the seastars of Japan II. Forcipulata, with the note on the relationships between the skeletal structure and respiratory organs of the sea-stars. Journal of the Faculty Science of Hokkaido Imperial University, Series 6, Zoology, 8:133-281.

Lee TJ, Shin S, 2009. A newly recorded sea star of the genus Lophaster (Asteroidea: Velatida) from Korea. Korean Journal of Systematic Zoology, 25:331-333.

Lee T, Shin S, 2010. A new record of Stephanasterias albula (Asteroidea: Forcipulata: Asteriidae) form the East Sea, Korea. Korean Journal of Systematic Zoology, 26:345-348.

Mah CL, 2009. World Asteroidea database [Internet]. The world register of marine species (WoRMS), Accessed 16 Mar 2009, <http://www.marinespecies.org/asteroidea>.

Rho BJ, Shin S, 1980. A systematic study on the echinoderms in Korea 4. Asteroids. Journal of Korean Resources Institute of Better Living, Ewha Womans University, 26:65-104.

Shin S, 1995. A systematic study on the Asteroidea in Korea 1. Species from the East Sea. Korean Journal of Systematic Zoology, 11:243-258.

Shin S, 2010. Sea stars: invertebrate fauna of Korea. National Institute of Biological Resources, 32:1-150.

Shin S, Rho BJ, 1996. Illustrated encyclopedia of fauna \& flora of the Korea, Vol. 36. Echinodermata. Ministry of Education, Seoul, pp. 1-780.

Received May 13, 2011 Accepted June 15, 2011 